\title{
河川敷上の樹木に作用する 流体抗力解析とその検証 ANALYSIS OF FLOW DRAG FORCE ACTING ON TREES VEGETATED IN FLOODPLAIN AND VERIFICATION OF THE MODEL PERFORMANCE
}

\author{
道奥康治 ${ }^{1} \cdot$ 谷口麻衣 $^{2} \cdot$ 魚谷拓矢 ${ }^{2} \cdot$ 阿河一穂 $^{3} \cdot$ 神田佳一 ${ }^{4}$ \\ Kohji MICHIOKU, Kazuho AGA, Mai TANIGUCHI, Takuya UOTANI and Keiichi KANDA

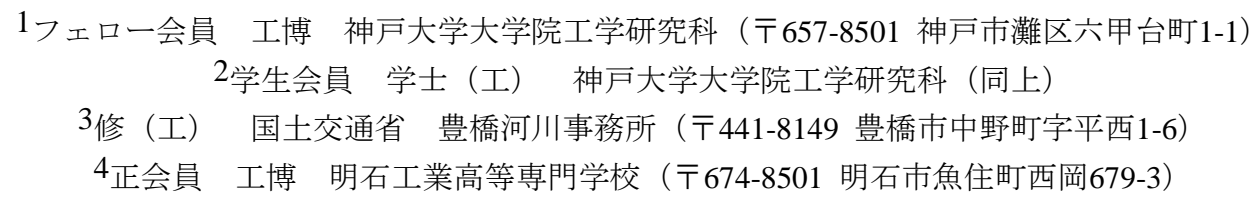

From technological and ecological viewpoints, it is a critical issue to control overgrowth of trees vegetated in floodplains. The authors have developed a hydraulic model which is able to describe flow and drag force in vegetated channels. The model has a two-layer structure in order to analyze both the slow flow through the vegetation and the fast flow over and besides the vegetation. The model was already confirmed to have a satisfactory reproducibility of flood flow structure through the authors' previous studies. In the present study, by collecting additional field data of trees and flood events, the model's performance in identifying areas and amounts of destructed trees was verified. The model could be a useful engineering tool for making a proper ecological management of tree vegetation and channel restoration projects.

Key Words : 2D and 2-layers flow model, vegetated channel, drag force

\section{1. 序論}

人為影響が及ぶ世界の多くの河川では，河道内の樹林 化が進行している，樹木の繁茂は，河積阻害・流水抵抗 により河川の疎通能力を低下させ，流木の生産源になる など，治水上の障害をもたらす。一方，かつては砂礫で 構成され動的平衡状態にあった河川敷が陸地化するため に水際遷移帯が失われて水陸の二極化が顕在化する.こ れによって, 河川敷は特定種の樹木に覆われ生態系が単 調化する. 樹木の過剰繁茂は水際へのアクセスを阻害し, 河川の親水機能が著しく低下する.

樹林化した河道における流水疎通能・抵抗特性, 樹林 帯からの流木発生量, 流水撹乱を利用した樹林化抑制管 理，樹林内の土砂動態，など技術的諸課題に取り組むた めには，樹林が繁茂した河道の流動特性と樹木に作用す る流体力の合理的評価が欠かせない.

樹林化した河道の流れは，これまで平面二次元モデル や縦断面一次元モデル，横断面一次元モデルによって記 述されてきた ${ }^{1) 4)}$. これらにおいては，樹木が付加的な
壁面粗度あるいは抗力要素として扱われ，水深平均流速 を用いてその抵抗力が記述されている5). しかし，大き な流量では樹木が冠水し, 樹林帯内の透過流は低速で, 樹林帯上の越流部や樹林の低水路側の流れは高速である ため，速度せん断が発生し流れの動力学を支配している. したがって, 治水上重要となる大規模出水や, 低木・幼 木の樹林帯を通過・越流する場合の流れの解析では, こ うした流れの鉛直せん断を考慮して樹林帯内外の流れや 流体力を評価する必要がある.

著者らは，多孔体構造物が設置された河川流を対象と する二次元二層流モデル ${ }^{6}$ を樹林化した河道の流れに応 用し，樹林帯内を透過する低速流と樹林帯上を越流する 高速流を再現できる二次元二層流モデル（「2D2Lモデ ル」と略記する）を定式化した7). また，加古川の樹林 繁茂区間を対象にH-ADCPによる洪水観測と樹木の生 育・倒伏状況調査を継続し，いくつかの出水イベントに 対して2D2Lモデルの流速再現性を検討した ${ }^{8)}$.2004年10 月（台風第23号）と2009年8月の二つの出水を対象とし て洪水流を解析し, 倒伏樹木の位置と2D2Lモデルから 算出される抗力モーメントの分布との相関性が高いこと 
をおおよそ確認した ${ }^{8}$.

過年度の研究において流速観測データとの比較から 2D2Lモデルの適用性を検証してきたが，以下の二点が 課題として残っている.

(i) 樹木の位置 - 成長度, 出水規模と樹木倒伏特性と の定量的関係.

(ii) 樹林帯内および樹冠上層における流速計測值と 2D2Lモデルとの比較.

その後, 樹林帯が冠水するような顕著な出水が今日ま でに複数回発生し, 流速・水位データの蓄積に成功した. また, 調査範囲を拡げて出水前後の現地踏查を継続し,

より詳細な樹木データを収集するとともに，倒伏・非倒 伏樹木の同定を積み重齐た，本研究では，対象と寸る河 川敷を流勢・樹木特性が異なる複数の小領域に分割して, 領域・出水別に流体抗力モーメントと樹木倒伏・非倒伏 を比較し，上記の課題(i)を検討する. また，課題(ii)の解 決を目指して，2012年度からは樹林帯内に流速・水位計 を設置し，計測・監視を続けてきた，当該機器は2013年 9月の大規模出水を捉えた模様であるが，流速に関する 「観測一解析」間の比較にまでは至っていない. 本研究では, 過年度の出水によって二層流状態が発生 している水際低木部を中心に樹林帯の抗力モーメントを 2D2Lモデル解析によって推定し，倒伏実績との比較か ら解析の妥当性を検証する.

\section{2. 河道内樹林の特性}

図-1のように一級水系加古川の河口距離23.2 24.0km を対象とする．この区間はセグメント 2.1 の中流域に属 し, 河床勾配は約 $1 / 800$ である. 樹林化が進行する以前 には河床材料粒径が数 $\mathrm{cm}$ 数十 $\mathrm{cm}$ であったが, 砂州固 定後の樹林化した高水敷・砂州表層においては，平均粒 径が砂州中央部で $2.8 \mathrm{~mm}$, 水際部で $6.6 \mathrm{~mm}$ の細粒土砂が 堆積している.「A. 右岸下流側」と「B. 左岸上流側」 は2009年に本研究を開始した当初から観測を続けており，
樹木個体の特性值が得られている. 本研究では, この二 領域に焦点をおいて数值解析から得られる抗力モーメン 卜と倒伏実績を定量的に比較し2D2Lモデルの再現性能 を検証する.

$\mathrm{A}, \mathrm{B}$ 二領域の区分を図-2に示寸，先の研究自では，樹 林を一括して取り扱い, 密生度, 樹径, 樹高が一定と仮 定して洪水流解析を実施したが，現地調查による情報が 蓄積されたため, 本研究では樹木特性や生育位置の類似 する樹木群を，同図の丸番号で示すようにグルーピング した. ただし，Aの11は堤防法尻に分布する竹林で屈堯 性が高く倒伏しないため, 流れの解析では粗度要素とし てのみ考慮し, 抗力モーメント解析の対象とはしない.

$\lceil\mathrm{C}$. 右岸上流側」は，2008年3月に高水敷を $1 \sim 1.5 \mathrm{~m}$ 掘 削した領域で，当初は裸地であったが，幼木が再繁茂し 始めた2010年11月から樹木調査を開始した． A, Bの二領 域に比べて個体数が多く全数調査が困難なため, 図中の ように一部の領域ではベルトトランセクト調査を実施し ている. C領域では樹高が小さく, 竹林と同様に抗力 モーメント解析の対象ではない.

樹木の位置，樹径（胸高直径）, 樹高の個体調査は, 主に「A. 右岸下流側」で2011年3月5日，「B. 左岸上流 側」で2010年3月13日に実施した。両日以外にも樹木倒 伏調査は各季に実施した（後述）。A，B領域で得られた 樹高・樹径の分布をそれぞれ図-3, 4に示寸. 図が煩雑と なるため, 領域の着色・ナンバリングを割愛しているが, 黒線の枠は図-2の領域境界に対応している. 表-1には竹 林を除く各領域の樹木数および密度・樹高の領域内平均 值を示す．未踏査の領域や未計測の樹木諸量については, 周辺状況と既往の知見から推定した（同表のハッチ部）.

「A. 右岸下流側」（図-2(a), 図-3, 4, 表-1）に着目寸 ると, 領域(2)水際水衝部に位置して水流攪乱を受ける 頻度が高いため，樹高 $5 \mathrm{~m}$ 以下で樹径の小さな幼木が多 い. 領域(3)も樹林上流端の水衝部であるが，(2)上りも堤 防に近く水深・流速が小さいため, 樹高は $7 \mathrm{~m}$ 程度と領 域(2)に比べれば大きい. また，竹林近傍にある領域(4), (5)は，竹林の水流緩和により流水擋乱を受けにくく，樹 高 $10 \mathrm{~m}$ 以上の樹木が確認される. 竹林の直下流にある領

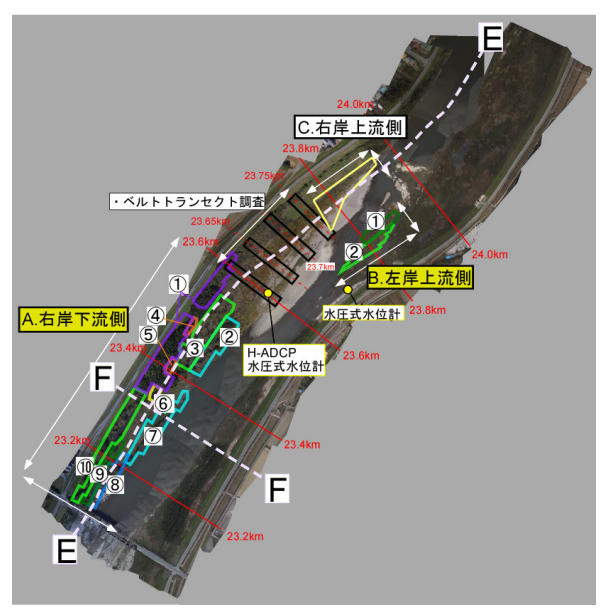

図-1＼cjkstart対象区間の領域設定と調査内容

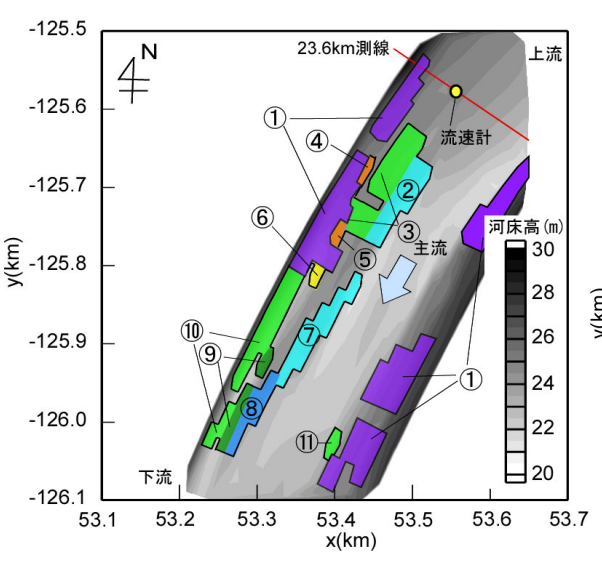

(a) A. 右岸下流側

図-2「A. 右岸下流側」と

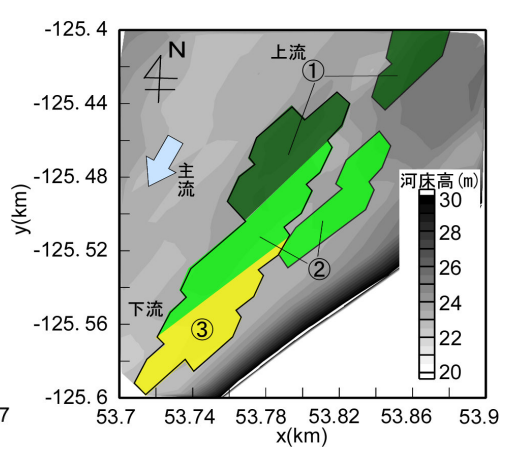

(b) B. 左岸上流側 


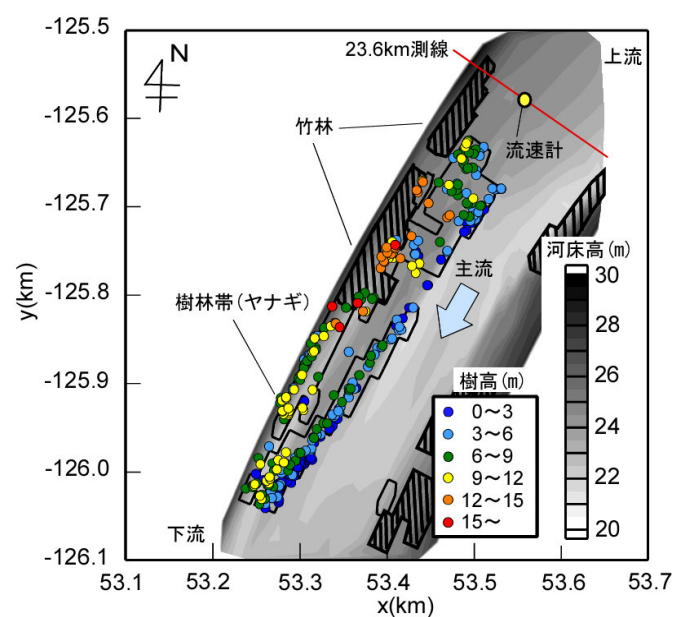

(a) A. 右岸下流側

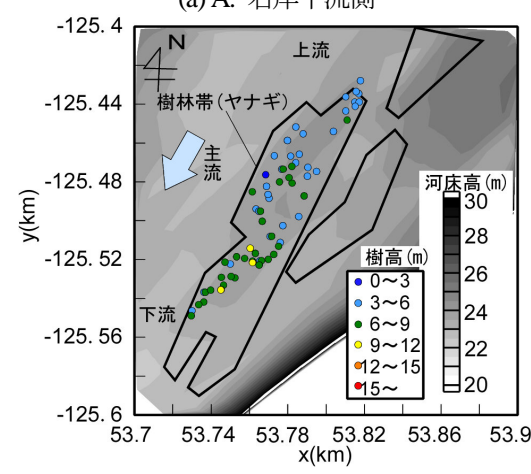

(b) B. 左岸上流側

図-3＼cjkstart樹高の分布（黒枠は図-2の領域に対応）

域(6でも樹高10m以上にまで生育している，一方，砂州 高水敷下流の水際にある領域(7)，8では，樹高5m程度 の樹木が高密度に繁茂している，上流から輸送されてき た枝葉が頻繁に活着（栄養繁殖）して高い密生度をもた らすが，流水擋乱も受けやすく大木へと生育しにくい環 境にある. 領域(7)，8よりも水際から遠い領域(9)，(10で は，樹高7 8m程度にまで生育している，このように密 度の高い水際植生の前面に大規模出水などで土砂が堆積 すると大木に生長し，新たな砂州水際で幼木が密生し始 めるというヤナギ特有の生態サイクルが観察される.

\section{3. 中小出水にともなう樹木倒伏の検証}

表-2に「A. 右岸下流側」の各領域における出水毎の 倒伏実績を示す。「倒伏樹木本数」とは，前回と当該の 調査との間に倒伏したと判定される樹木数であり，期間 内に複数の出水が発生した場合には最大流量時に倒伏し たと考えた.「樹木倒伏率」は領域内の全樹木に占める 倒伏樹木の割合である．若干の樹木は未確認である．な お，出水後には上流から輸送されたゴミ・枝葉など多く の夾杂倠物が樹木に捕捉・蓄積されて，抗力の作用面積が 樹径相当より大きく, 実流速は小さいと考えられる. し かし, 現時点では出水時の夾雑物フラックスや樹木への 捕捉・蓄積量を評価する適切な手段がない. 本研究では

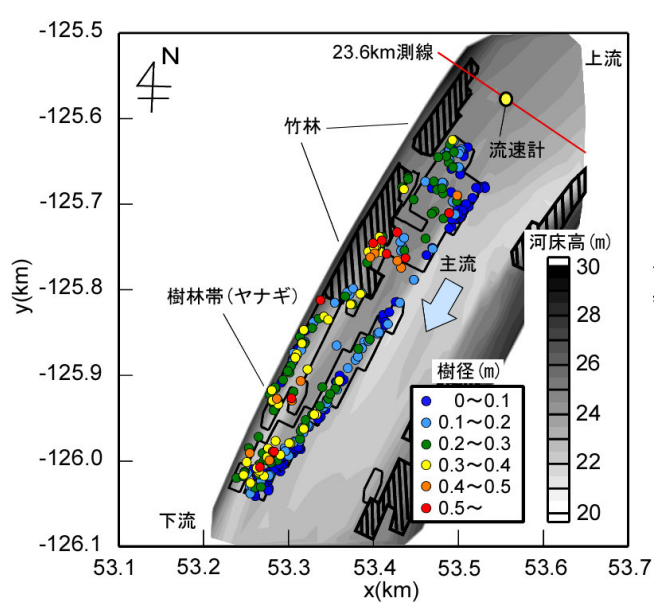

(a) A. 右岸下流側

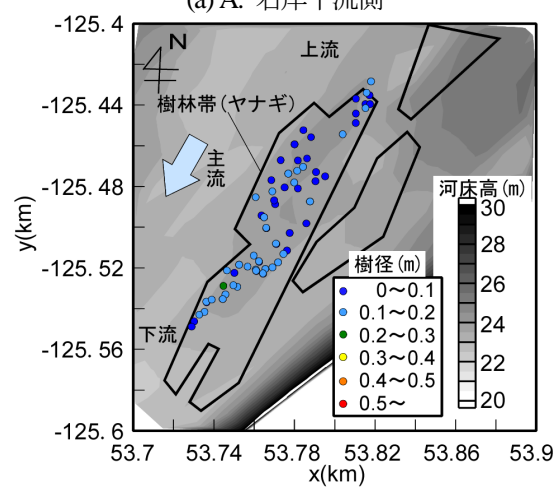

(b) B. 左岸上流側

図-4 樹径の分布（黒枠は図-2の領域に対応）

樹径・水深・密生度によって倒伏モーメントを評価》し ているが，倒伏実績と解析結果との比較においては，こ れらを含む現地固有の予測不能要因も影響している可能 性がある. 夾雑物の閉塞・流水阻害効果については今後 の研究課題と位置づけられる.

表-2から，水衝部である領域(2)，(3)の樹木倒伏率は $70 \%$ 以上と高く, 出水時の流水摚乱が卓越していること がわかる. 特に, 領域(2)では90\%以上の樹木が倒伏して いる. 下流側水際部にある領域(7)，8においても70\%の 樹木が倒伏している. なお, 領域(9は水際から一定の距 離を隔しているにも関わらず，倒伏率が50\%程度に至っ

表-1 各領域の樹木分布（領域平均値，ハッチは推定值）

\begin{tabular}{|c|c|c|c|c|c|c|c|c|}
\hline 位置 & $\begin{array}{l}\text { 領域 } \\
\text { 番号 }\end{array}$ & 樹種 & $\begin{array}{l}\text { 個体 } \\
\text { 数 }\end{array}$ & $\begin{array}{l}\text { 概算面 } \\
\text { 積 }\left(\mathrm{m}^{2}\right)\end{array}$ & $\begin{array}{l}\text { 密度 } \\
N\left(\mathrm{~m}^{-2}\right)\end{array}$ & $\begin{array}{l}\text { 樹径 } \\
d(\mathrm{~m})\end{array}$ & $\begin{array}{c}\text { 密生度 } \\
\lambda_{\text {veg }}\left(\mathrm{m}^{-1}\right)\end{array}$ & $\begin{array}{l}\text { 樹高 } \\
h_{\mathrm{V}}(\mathrm{m})\end{array}$ \\
\hline \multirow{11}{*}{$\begin{array}{l}\text { A. 右 } \\
\text { 岸下 } \\
\text { 流側 }\end{array}$} & \multirow{11}{*}{$\begin{array}{l}1 \\
(2) \\
(3) \\
(4) \\
(5) \\
(6) \\
(7) \\
(8) \\
(9) \\
(10) \\
\text { (11) }\end{array}$} & \multirow{5}{*}{$\begin{array}{c}\text { 竹 } \\
\text { ヤナギ } \\
\text { ヤナギ } \\
\text { ヤナギ } \\
\text { ヤナギ }\end{array}$} & - & $\overline{-1}$ & - & 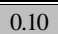 & "0.21 & 8.0 \\
\hline & & & 44 & 2,000 & 0.022 & 0.10 & 0.002 & 4.6 \\
\hline & & & 53 & 2,400 & 0.022 & 0.21 & 0.005 & 7.2 \\
\hline & & & 4 & 200 & 0.020 & 0.53 & 0.011 & 12.6 \\
\hline & & & 26 & 200 & 0.130 & 0.48 & 0.062 & 11.8 \\
\hline & & ヤナギ & 8 & 200 & 0.040 & 0.38 & 0.015 & 10.3 \\
\hline & & ヤナギ & 45 & 1,800 & 0.025 & 0.12 & 0.003 & 5.0 \\
\hline & & ヤナギ & 72 & 1,000 & 0.072 & 0.06 & 0.004 & 3.3 \\
\hline & & ヤナギ & 41 & 1,000 & 0.041 & 0.19 & 0.008 & 6.8 \\
\hline & & ヤナギ & 57 & 2,200 & 0.026 & 0.28 & 0.007 & 8.5 \\
\hline & & ヤナギ & - & - & - & 0.24 & 0.008 & 7.8 \\
\hline B. 左 & (1) & ヤナギ & 37 & 800 & 0.046 & 0.13 & 0.006 & 5.4 \\
\hline 岸上 & (2) & ヤナギ & 38 & 1,000 & 0.038 & 0.23 & 0.009 & 7.5 \\
\hline 流側 & (3) & ヤナギ & - & - & - & 0.38 & 0.015 & 10.3 \\
\hline
\end{tabular}


表-2「A. 右岸下流側」の各領域における出水毎の倒伏調査結果（数字は倒伏樹木本数）

\begin{tabular}{|c|c|c|c|c|c|c|c|c|c|c|c|}
\hline \multicolumn{2}{|c|}{ 出水発生日 } & 不明 & 2009年以前 & $\begin{array}{c}\text { 2009年 } \\
\text { 8月1-2日 }\end{array}$ & $\begin{array}{c}\text { 2010年 } \\
\text { 5月23-25日 }\end{array}$ & $\begin{array}{c}\text { 2011年 } \\
\text { 5月29-30日 }\end{array}$ & $\begin{array}{c}\text { 2011年 } \\
\text { 9月3-4日 }\end{array}$ & $\begin{array}{c}\text { 2011年 } \\
\text { 9月20-21日 }\end{array}$ & \multirow{3}{*}{$\begin{array}{c}\text { 領域内 } \\
\text { の累積 } \\
\text { 倒伏数 } \\
\text { (A) }\end{array}$} & \multirow{3}{*}{$\begin{array}{c}\text { 領域内 } \\
\text { の全樹 } \\
\text { 木数 } \\
\text { (B) }\end{array}$} & \multirow{3}{*}{$\begin{array}{l}\text { 倒伏率 } \\
\mathrm{A} / \mathrm{B} \times \\
100(\%)\end{array}$} \\
\hline \multicolumn{2}{|c|}{$\begin{array}{c}\text { ピーク流量 } \\
Q_{\max }\left(\mathrm{m}^{3} / \mathrm{s}\right)\end{array}$} & - & - & $1,459.91$ & $3,227.07$ & $1,762.32$ & $3,590.65$ & $2,393.16$ & & & \\
\hline \multicolumn{2}{|c|}{ 倒伏確認日 } & $\begin{array}{l}\text { 2011年 } \\
\text { 3月5日 }\end{array}$ & $\begin{array}{l}\text { 2011年 } \\
\text { 3月5日 }\end{array}$ & $\begin{array}{l}\text { 2011年 } \\
\text { 9月6日 }\end{array}$ & $\begin{array}{l}\text { 2011年 } \\
3 \text { 月5日 }\end{array}$ & $\begin{array}{l}\text { 2011年 } \\
\text { 6月19日 }\end{array}$ & $\begin{array}{c}\text { 2011年 } \\
\text { 9月11日 }\end{array}$ & $\begin{array}{c}\text { 2011年 } \\
\text { 11月23日 }\end{array}$ & & & \\
\hline \multirow{9}{*}{$\begin{array}{l}\text { 領域 } \\
\text { 番号 } \\
\text { [A.右岸 } \\
\text { 下流則 }\end{array}$} & (2) & 20 & 3 & 0 & 1 & 2 & 12 & 3 & 41 & 44 & 93.2 \\
\hline & (3) & 12 & 11 & 0 & 5 & 0 & 9 & 2 & 39 & 53 & 73.6 \\
\hline & (4) & 0 & 0 & 0 & 0 & 0 & 0 & 0 & 0 & 4 & 0.0 \\
\hline & (5) & 0 & 0 & 0 & 0 & 0 & 0 & 0 & 0 & 26 & 0.0 \\
\hline & (6) & 1 & 0 & 0 & 0 & 0 & 0 & 0 & 1 & 8 & 12.5 \\
\hline & (7) & 4 & 3 & 0 & 0 & 1 & 16 & 12 & 36 & 45 & 80.0 \\
\hline & (8) & 3 & 1 & 4 & 0 & 4 & 28 & 11 & 51 & 72 & 70.8 \\
\hline & (9) & 3 & 7 & 0 & 2 & 2 & 7 & 0 & 21 & 41 & 51.2 \\
\hline & (10) & 1 & 1 & 0 & 0 & 0 & 0 & 0 & 2 & 57 & 3.5 \\
\hline \multicolumn{2}{|c|}{ 小 計 } & 44 & 26 & 4 & 8 & 9 & 72 & 28 & 191 & 350 & 54.6 \\
\hline
\end{tabular}

ている. 領域(9は比高が小さく根鉢が小さいため樹木の 支持力が弱いと推察される。これに対し，樹高・樹径分 布（図-3，4）で確認されたように竹林を取り巻く領域(4), (5)，(6)では成長した樹木が多く（倒伏限界モーメント MCが大きい) ほとんど倒伏が確認されない.

\section{4. 二次元二層流 (2D2L) モデルの概要 ${ }^{7)}$}

二次元二層流モデル（2D2Lモデル） $)^{7}$ は樹冠を繋ぐ二 層境界面で河川流を上下二層に分割することで，樹冠上 の高速流と樹林内の低速流が生成する鉛直速度せん断を 表現し，上下層間の質量・運動量交換によって樹林がも たらす流水抵抗を表わす平面二次元流モデルである．も ちろん，林床の河床抵抗など，浅水流モデルに含まれる 動力学は全て考慮される. 二層境界面と河床面が交わる 浅い領域では一層流が形成され，浅水流モデルと同じ一 層流構造に設定している. しかし，樹林帯以外でも樹林 帯と同程度に大きな水深を有する領域では二層流を仮定 して，内部せん断効果を考慮できる構造としている．樹 林から離れた領域では，上下方向の運動量拡散により上 下層が均質化して一層流に復元し，浅水流モデルと同じ 河川流を再現できる．樹林化した河川の流れに関しては, $\mathrm{H}-\mathrm{ADCP}$ 計測值との比較を通して複数洪水の再現に成功 している ${ }^{8)}$. 本研究ほど樹木情報が整備された段階では なかったが，樹木が倒伏した領域で抗力モーメントが卓 越することなど，モデル性能を予備的に確認しており， 2D2Lモデルは樹木の倒伏・非倒伏特性を表現し得ると 考えている8.

\section{0423号台風出水を想定した予備解析}

\section{(1) 樹木の条件}

H.W.Lより高い樹木を除けば，ほとんどの樹木は計画 高水流量に対して冠水するため, 樹林透過流とその越流 層からなる二層流が形成される．樹木の冠水が流れに及 ぼす影響を明らかにするために，2D2Lモデルを用いて
表-3のような三つのCASEに対し，予備的な河川流解析 を実施した。

(i) CASE 1: 現行の河川地形で裸地を仮定 : 樹木なし の一層流（「2D2Lモデル＝浅水流モデル」の状態）.

(ii) CASE 2: 実績の樹木よりも高い樹高8mを一律に与 え，水際を除くほとんどの樹木が非冠水と仮定.

(iii) CASE 3: 樹木情報の実績值（図-3，4，表-1））を 与えた場合 : H.W.L.以上の樹林域と二層境界面よ り浅い河床の領域を除く全ての領域が二層流.

竹林の密生度 $\lambda_{\text {veg }}$ は既往の知見 $\left.{ }^{10}\right)$ に基づき与えられて いる. 対象外力とした2004年台風第23号の出水は，この 区間における戦後最大流量にほぼ匹敵している，表-2の 倒伏樹木調査結果の中で，本研究を開始した2009年以前 に倒伏した樹木のほとんどは，この出水により倒伏した と判断される. したがって，2009年以前の倒伏樹木を検 証する上でCASE3が参考になる。

\section{(2) 流速 · 水位の解析}

図-1の樹林帯中央を縦断するE-E断面における水面形 と河床形状を図-5に示寸。同図にはCASE 3 の樹林帯

（現状）と二層境界面のプロファイルが併記されている. 全潤辺が裸地のCASE 1に比べてCASE 2, CASE 3では 0.5 1.0mほど水位が上昇している. 全樹木の高さを一律 $h_{\mathrm{V}}=8.0 \mathrm{~m}$ に設定したCASE 2では水際の植生も大部分が冠 水しないため, CASE 3よりもかなり疎通能力が減少す る. 図-1のF-F横断面における全層平均流速の横断分布 を水面形，河床地形とともに図-6に示す，樹木を設定し たCASE 2,3では, CASE 1に比べ樹林帯で減速，低水路

表-3 予備解析の水理 · 樹木条件

\begin{tabular}{|c|c|c|c|c|}
\hline & & CASE 1 & CASE2 & CASE 3 \\
\hline \multicolumn{2}{|c|}{ 流量 $Q\left(\mathrm{~m}^{3} / \mathrm{s}\right)$} & \multicolumn{3}{|c|}{ 4,403.35 (台風0423号のピーク流量) } \\
\hline \multicolumn{2}{|c|}{ 下流端水位 EL.(m) } & \multicolumn{3}{|c|}{30.27 (同上出水の実績水位) } \\
\hline \multicolumn{2}{|c|}{ 粗度係数 $n\left(\mathrm{~m}^{-1 / 3} \mathrm{~s}\right)$} & \multicolumn{3}{|c|}{ 低水路 : 0.028 , 高水敷 : 0.055} \\
\hline \multirow{2}{*}{ 樹高 (m) } & ヤナギ & 0.0 & 8.0 & 実績 \\
\hline & 竹 & 0.0 & 8.0 & 8.0 \\
\hline \multirow{2}{*}{ 密生度 $\left(\mathrm{m}^{-1}\right)$} & ヤナギ & 0.0 & 0.01 & 実績 \\
\hline & 竹 & 0.0 & 0.21 & 0.21 \\
\hline \multirow{2}{*}{ 樹径 (m) } & ヤナギ & 0.0 & 0.2 & 実績 \\
\hline & 竹 & 0.0 & 0.1 & 0.1 \\
\hline
\end{tabular}


で加速されている. 水際に低木が分布する現況 (CASE 3）では実績よりも高い樹高（ $h_{\mathrm{V}}=8.0 \mathrm{~m} ）$ を想定した CASE 2 (水際で) よりも水際部における流速が卓越し ている. CASE 3においては鉛直方向の運動量交換に伴 う内部せん断力が二層境界面に発生するが, CASE 2で は，全水深にわたりそれ以上に大きな抗力が発生し流れ を阻害していることがわかる。これより，樹林化が進ん だ河川の疎通能力を評価するためには，樹木高を考慮し た二層流としての解析が必要であると考えられる.

\section{(3) 樹木に作用する抗力モーメント}

図-7(a), (b)には樹木に作用する倒伏モーメント比 $M_{\mathrm{V}} / M_{\mathrm{C}}$ の分布を示す.ここで $M_{\mathrm{V}}$ は樹木に作用する抗力 モーメント， $M_{\mathrm{C}}$ は樹木が倒伏する限界抗力モーメント である，本文では，倒伏調査を最も集中的に実施した

「A. 右岸下流側」の領域の結果のみを示寸. 図中の赤 丸は0423号台風により倒伏したと判定される樹木の位置 である. 実績の樹木特性を用いて0423号台風出水の $M_{\mathrm{V}} / M_{\mathrm{C}}$ を評価したCASE 3が，CASE 2よりも樹木倒伏実 績を良好に再現していることがわかる.

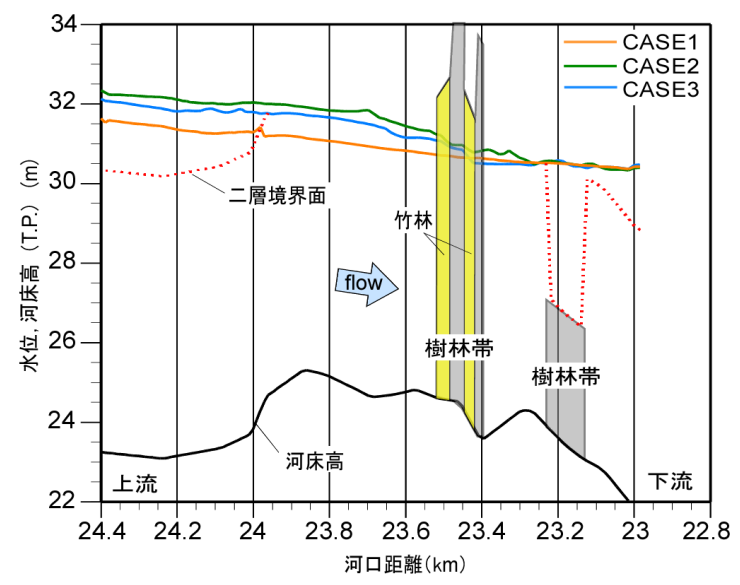

図-5 継断水面形分布

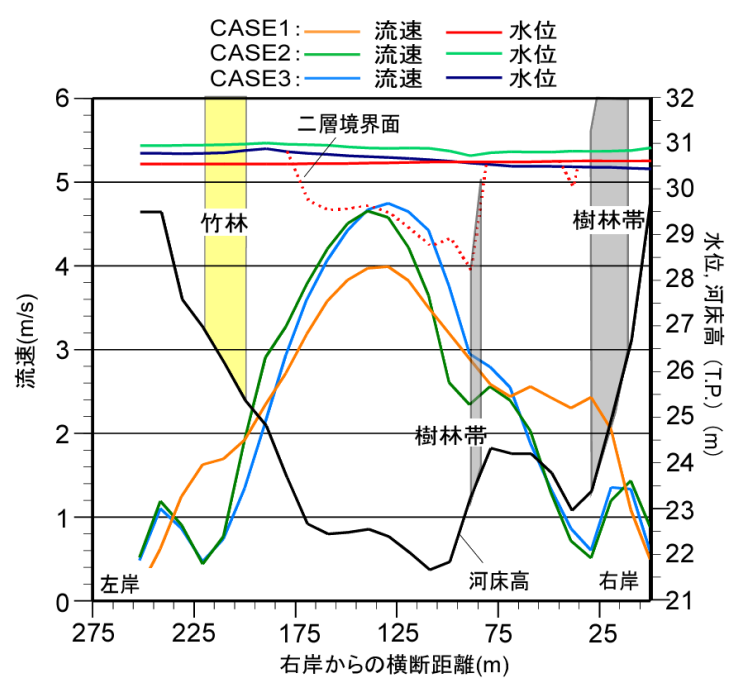

図-6 流速の横断分布

\section{6. 近年の中小出水における樹木倒伏と $M_{V} / M_{\mathrm{C}}$}

本研究を開始した2009年以降に発生した中小出水（表 -2参照）を対象に，2D2Lモデル解析を実施した．図-8は 解析から得られたピーク流量時における $M_{\mathrm{V}} / M_{\mathrm{C}}$ の平面分 布を示す. 当該出水によって倒伏したと推定される樹木 の位置を赤丸で記す. 図-9は各領域における $M_{\mathrm{v}} / M_{\mathrm{C}}$ の平 均值 $\overline{M_{\mathrm{V}} / M_{\mathrm{C}}}$ と当該出水における各領域の樹木倒伏率

（表-2から算出）を示す。両図を総合的に見れば, 2D2Lモデルにより各領域あるいは各出水に応じた倒伏 実績が良好に再現されていることがわかる。ただし， 2010年以前の調查では，倒伏状況が未確認の樹木も多い. 例えば，図-8(b)を見ると $M_{\sqrt{ }} M_{\mathrm{c}}$ が大きな水際部（領域(2)， (7), 8) でも倒伏樹木は確認されない. 樹木個体一のID 番号付け作業が完了した2011年以降のデータに限定すれ ば（図-8(c), 9(c)），解析と実測との対応関係はかなり良 好である.

\section{7. 結論}

本研究では, 樹林が冠水し鉛直・水平方向の速度せん 断が卓越するような河川流を想定し，二次元二層流

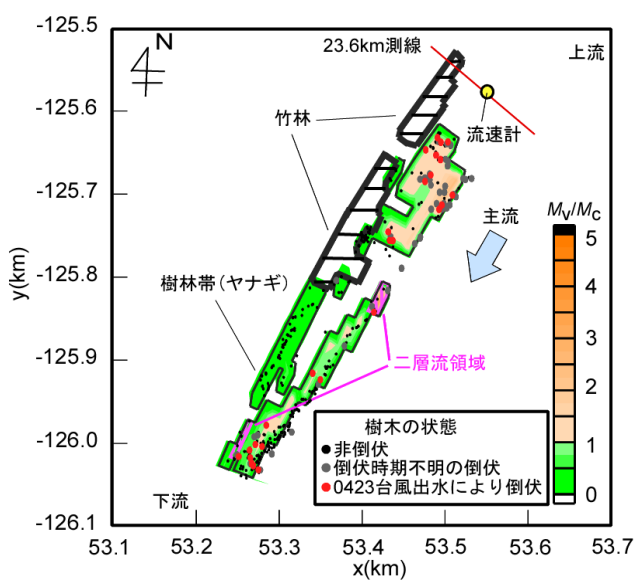

(a) CASE 2 (全樹高を一律 $8.0 \mathrm{~m}$ に設定)

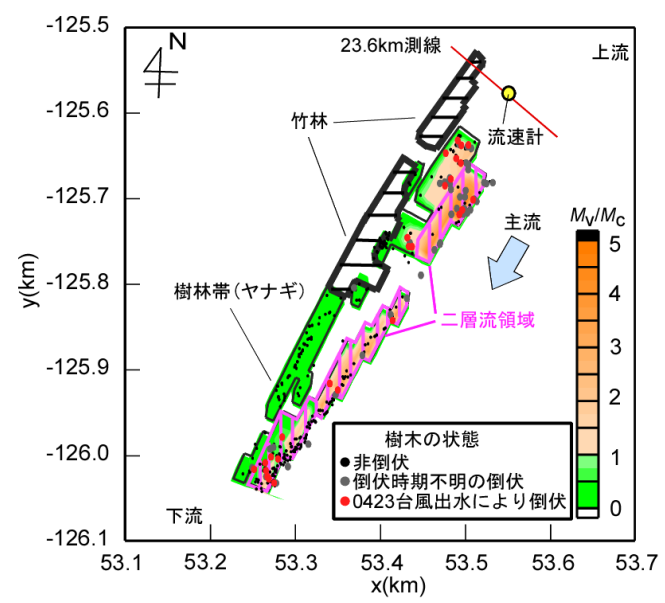

(b) CASE 3 (実測に基づく樹林分布)

図-7樹木に作用する倒伏モーメント比 


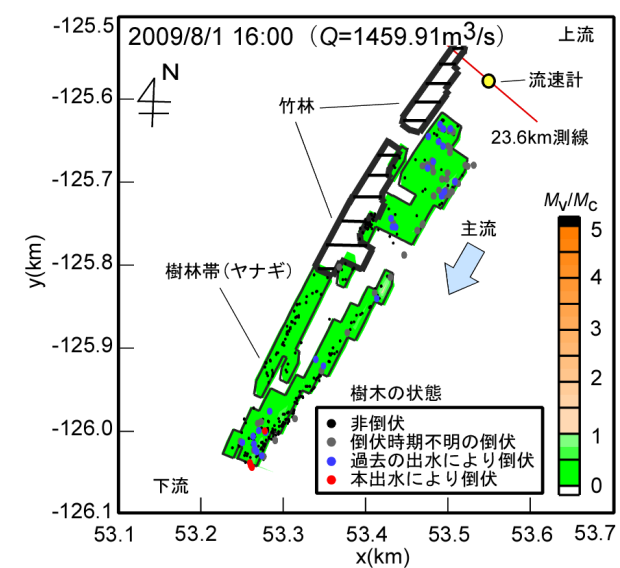

(a) 2009年8月1 2日の出水

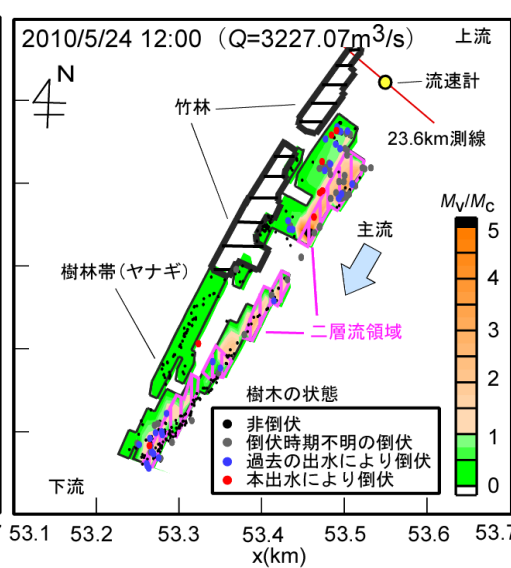

(b) 2010年5月23 25日の出水

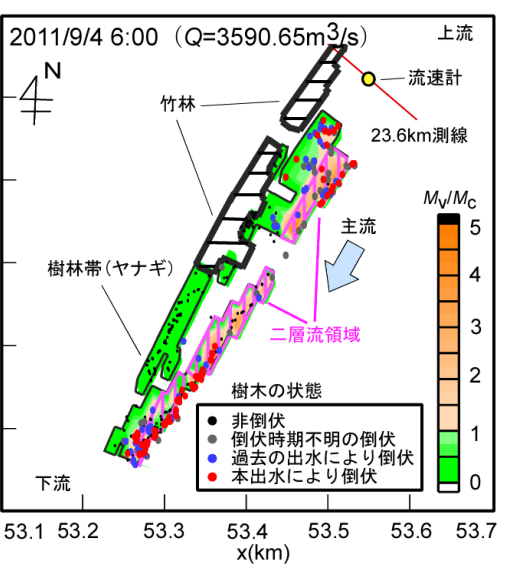

(c) 2011年9月3 4日の出水

図-8 倒伏モーメント比 $M / M$ Cと当該出水によって倒伏したと判定される樹木の位置（A. 右岸下流側）

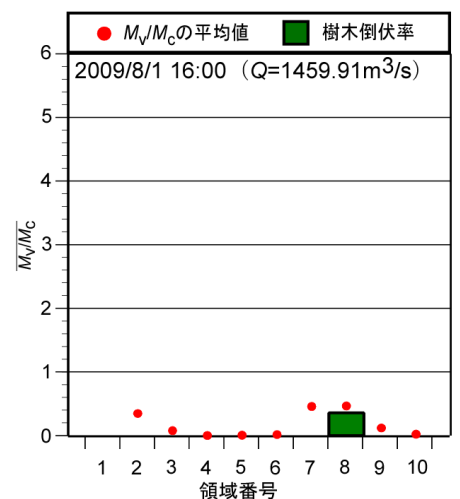

(a) 2009年8月1 2日の出水

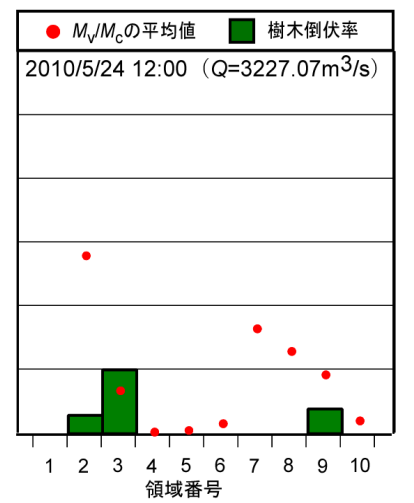

(b) 2010年5月23 25日の出水

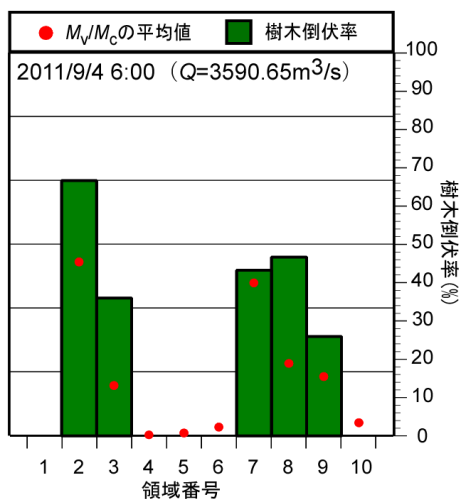

(c) 2011年9月3 4日の出水

図-9＼cjkstart各領域における平均倒伏モーメント比 $\overline{M_{\mathrm{v}} / M_{\mathrm{C}}}$ と倒伏率の比較

（2D2L）モデルを用いて洪水流と樹木に作用する抗力 モーメントを解析した．以下のように結論が要約される。

・2009-2011年にかけて河道内樹林の調査を実施した. 当該区間においては，水際水衝部のヤナギのほとんど が幼木であり，堤防に近く水際から離れた高い地盤で はヤナギが大きく成長していた.

・樹木が冠水した二層流状態での洪水流を再現するため に，2004年台風第23号の出水を対象として，樹木特性 が河川流や樹木抗力モーメントに及ぼす影響を照査し た. 樹林内と樹冠上層の流れを区別することにより， 樹木の流水阻害効果を適切に評価できることを示した。 ・2009〜2011年に発生した中小洪水による抗力モーメン 卜を2D2Lモデルにより解析し，出水毎・領域別の樹 木倒伏実績が良好に再現されることを確認した。

謝辞 : 本研究を実施するにあたり，国土交通省姫路河川 国道事務所の関係者にご協力頂いた。本研究は，平成 23-25年(2013)度科学研究費基盤研究(B)（代表 : 道奥康 治, 課題番号: 23360212）の助成の下で実施された.

\section{参考文献}

1) 前野詩朗・宮内洋介・森卓也 : 植生が旭川の洪水流に及ぼす 影響の検討，水工学論文集，第48巻，pp.757-762，2004.

2) 清水義彦・小葉竹重機・新船隆行 : 樹林化河道の洪水流況々 浮遊砂輸送に関する数值計算, 水工学論文集, 第44巻, pp.819-824, 2000.

3) 重枝未玲・朝位孝二 ・坂本洋・徳永智宏・西尾崇・秋山壽一 郎・中江邦昭 : 拡張準二次元解析を用いた大野川・乙津川の 河道内樹木の管理に関する研究, 水工学論文集, 第 52 巻, pp.655-660, 2008.

4) 後藤岳久 - 福岡捷二 ・ 児子真也 $・$ 中須賀淳 : 複断面蛇行河道 における洪水流による樹木群の倒伏・破壊機構と樹木管理一 の活用，土木学会論文集B，Vol.66 No.1，pp.47-65， 2010.

5) 福岡捷二 ・佐藤宏明 - 藤澤宽 - 大沼史佳 : 洪水流と河道の樹 木繁茂形態に基づく樹木群透過係数と粗度係数の算定法, 水 工学論文集, 第51巻, pp.607-612, 2007.

6) 道奥康治・南條雅志・石垣泰輔・前野詩朗 : 捨石水制が冠水 した開水路流の二次元二層流モデル，土木学会論文集, No.782/II-70, pp.31-50, 2005.

7) 道奥康治他 : 樹林化した河道の流況観測と樹林内外の流況 樹木抗力の解析，河川技術論文集，第16巻，pp.437-442, 2010.

8) 道奥康治・宮本仁志・神田佳一 ・大地洋平 : 樹林か繁茂した 加古川中流部における出水時流況之樹林損壊に関寸る調查 解析，水工学論文集，第55巻，pp.S_1087-S_1092， 2011.

9) (財)リバーフロント整備センター編 : 河川における樹木管 理の手引き, 山海堂, pp.157, 1999.

10) 岡部健士・田村隆雄 : 吉野川河道内に残留した水防竹林の 管理計画に関する数值解析的検討, 水工学論文集, 第 53 巻, pp.625-630, 2009.

(2013. 9. 30受付) 